\title{
Demographic, clinical, and laboratory parameters of cystic fibrosis during the last two decades: a comparative analysis
}

\author{
Fernando Augusto de Lima Marson ${ }^{1,2^{*}}$, Tais Daiene Russo Hortencio ${ }^{1}$, Katia Cristina Alberto Aguiar ${ }^{1}$,
} Jose Dirceu Ribeiro ${ }^{1}$ and CYFIUC Group

\begin{abstract}
Background: In recent years, patients with cystic fibrosis (CF) have tended to experience a longer life expectancy and higher quality of life. In this context, the aim of the present study was to evaluate and compare the demographic, clinical, and laboratory markers of patients with CF during the last two decades at a CF referral center.

Methods: A retrospective study of the demographic, clinical, and laboratory markers for CF treatment at a CF referral center was performed during two decades: 2000 (DI, 1990-2000, $n=104$ patients) and 2010 (DII, 2000-2010, $n=181$ patients).

Results: The following variables were less common in DI than in DII: (i) pancreatic insufficiency, (ii) meconium ileus, (iii) diabetes mellitus, (iv) Burkholderia cepacia colonization, (v) moderate and severe Shwachman-Kulczycki score (SKS), (vi) F508del mutation screening, (vii) patients without an identified CFTR mutation (class IV, V, or VI mutation), (viii) patients above the 10th percentile for weight and height, (ix) restrictive lung disease, and (x) older patients ( $p<0.01$ ). The following variables were more common in DI than in DII: (i) excellent and good SKS, (ii) F508del heterozygous status, (iii) colonization by mucoid and nonmucoid Pseudomonas aeruginosa, (iv) obstructive lung disease, and $(v)$ minimal time for CF diagnosis $(p<0.01)$.

Conclusion: Clinical outcomes differed between the two decades. Demographic, clinical, and laboratory markers in patients with CF are useful tools and should be encouraged in CF referral centers to determine the results of CF management and treatment, enabling a better understanding of this disease and its clinical evolution. Early diagnosis and management of CF will improve patients' quality of life and life expectancy until personalized drug therapy is possible for all patients with CF.
\end{abstract}

Keywords: Cystic fibrosis, Epidemiology, Lung disease

\section{Background}

The advances in knowledge of cystic fibrosis (CF: \#219700) have been striking in recent decades. Identification of the cystic fibrosis transmembrane regulator gene (CFTR) (region 7q3.11) [1-3], with nearly 2,000 mutations identified in 2014 [4-6], has provided the knowledge base for the genotypic and phenotypic characteristics of CF. CFTR mutations lead to the absence or dysfunction

\footnotetext{
* Correspondence: fernandolimamarson@hotmail.com

'Departments of Pediatrics, State University of Campinas - Unicamp, Faculty of Medical Sciences, Campinas, Brazil

${ }^{2}$ Departments of Medical Genetics, State University of Campinas - Unicamp, Faculty of Medical Sciences, Campinas, Brazil
}

(quantitative and/or qualitative) of the CFTR protein, altering chloride transport at the cell surface. This causes a compensatory influx of sodium to maintain electroneutrality and a consequent influx of water, extracellular dehydration, and formation of thick mucus in the airways [7]. Classic CF is characterized by pulmonary and gastrointestinal symptoms in the first few months of life [8].

The clinical manifestations of $\mathrm{CF}$ are variable, even among patients with the same CFTR mutation $[9,10]$. Advances in $\mathrm{CF}$ treatment in the last several years are related to therapies aimed at improving the quality of life and management of the disease. These therapies include inhaled drugs, respiratory therapy, individualized outpatient 
care, treatment of comorbidities, genetic counseling, dietary adaptation of pancreatic enzymes, nutritional supplements, neonatal screening by immunoreactive trypsinogen (IRT), antibiotic therapy, lung transplantation, and, more recently, personalized drug therapy [i.e., ivacaftor for G551D (rs75527207, c.1652G > A) mutation and eight other mutations approved by the US Food and Drug Administration] [11,12].

In developing countries, recent studies on CF are scarce and a poor understanding of patient management and CF progression during follow-up care exists in referral centers. In this context, the aim of the present study was to evaluate and compare the demographic, clinical, and laboratory markers in patients with CF treated at a referral center in the last decade of the 20th century (DI) and the first decade of the 21st century (DII).

\section{Methods}

A retrospective study in a CF referral center was performed. Demographic, clinical, and laboratory data were obtained from 104 patients with CF seen in the last decade of the 20th century, from 1990 (time zero) to 2000 (DI); all data were collected from the patients' medical records in the year 2000 [13]. The same data were obtained from 181 patients with CF treated in the first decade of the present century, from 2001 (time zero) to 2010 (DII); all data were collected from the patients' medical records in the year 2011. The number of patients with CF enrolled in both decades equaled the total number of patients with CF followed at the referral center in the stipulated timeframe. The diagnosis of CF was confirmed by two sweat tests with chloride concentrations of $>60 \mathrm{mEq} / \mathrm{L}$ (gold standard diagnostic tool) and/ or identification of two CFTR mutations. Patients with $\mathrm{CF}$ who had undergone lung transplantation were not enrolled.

\section{Demographic, clinical, and laboratory markers}

The demographic, clinical, and laboratory variables analyzed in this study were sex (male/female), ethnicity (Caucasian or non-Caucasian), age, age range, number of deaths, clinical manifestations (respiratory and digestive), age at diagnosis, comorbidities [pancreatic insufficiency (PI), meconium ileus (MI), and diabetes mellitus (DM)], nutritional status as determined by weight and height on a growth curve (weight and height below the 10th percentile), oxygen saturation $\left(\mathrm{SpO}_{2}\right)(>95 \%, 91 \%-95 \%$, or $<91 \%)$, sweat chloride level, microorganisms in the sputum (Staphylococcus aureus, mucoid and nonmucoid Pseudomonas aeruginosa, and Burkholderia cepacia), spirometry findings (normal, restrictive lung disease, obstructive lung disease, or mixed respiratory disorder) [14], genetic screening for the CFTR mutations [F508del (rs113993960, c.1521_
1523delCTT), G542X (rs113993959, c.1624G > T), N1303K (rs80034486, с.3909C > G), G551D, R553X (rs74597325, c.1657C > T), and W1282X (rs77010898, c.3846G > A)], Shwachman-Kulczycki score (SKS) (excellent or good, mild, or moderate or severe) [15], and fecal fat.

\section{Spirometry}

Spirometric testing was performed according to the following American Thoracic Society standards [14]:

(i). Obstructive lung disease: less than the 5 th percentile of the ratio of the predicted forced expiratory volume in the first second to the forced vital capacity $\left(\mathrm{FEV}_{1} / \mathrm{FVC}\right)$. Reduction of flow in a patient with low lung volume is not specific to small airway disease. Concomitant decreases in $\mathrm{FEV}_{1}$ and FVC are commonly caused by poor effort, but can rarely reflect airflow obstruction. Confirmation of airway obstruction requires lung volume measurement.

(ii). Restrictive ventilatory disturbance: total lung capacity below the 5 th percentile of the predicted value. Reduced FVC does not prove the presence of a restrictive lung defect, but is suggestive of pulmonary restriction when the $\mathrm{FEV}_{1} / \mathrm{FVC}$ is normal or increased.

(iii). Mixed respiratory disorder: $\mathrm{FEV}_{1} / \mathrm{FVC}$ and lung capacity below the 5 th percentile of the predicted value.

Spirometric testing was performed in patients $>7$ years of age using a CPFS/D spirometer (Medical Graphics Co., Saint Paul, MN, USA). The data were recorded by PF BREEZE software vs 3.8B for Windows 95/98/NT (Medical Graphics Co.) [14].

\section{SKS analysis}

The SKS was determined by two previously trained professionals, and in case of disagreement, a third evaluator was considered [15].

\section{Sputum collection}

The patients' sputum was collected by spontaneous sputum sampling, induction by physiotherapy maneuvers, or collection of oropharyngeal swabs for analysis of the microorganism colonizing or infecting the airways. Examinations were performed in the Pathology Laboratory at the Clinical Hospital of the State University of Campinas.

IRT was implemented in our center in 2010. Therefore, the comparative analysis of the two decades did not include patients with CF who underwent neonatal screening. 


\section{Statistical analysis}

The Statistical Package for the Social Sciences v.21.0 (SPSS, Inc., Chicago, IL, USA) was used for statistical analysis [16]. For descriptive analysis, we used mean, median, and standard deviation for continuous variables and absolute frequency (percentage) for categorical variables. Fisher's exact test and the $\chi^{2}$ test were performed to compare the groups using categorical variables. In cases of differences in the data between the periods analyzed, the odds ratio (OR) and 95\% confidence interval (95\% CI) were calculated. The alpha value was 0.05 . The Ethics Committee in Research of the State University of Campinas (\#508/2008) approved this study.

\section{Results}

Table 1 compares the demographic, clinical, and laboratory variables of the patients with CF enrolled in this study in the two above-described decades.

The following markers showed an association between the two decades: digestive symptoms, comorbidities, height and weight, microorganisms, spirometry, SKS, F508del screening, and age range (Tables 2, 3, 4 and 5).

An overview of all data analyzed is shown in Figure 1. Comparison of DI with DII revealed the following in DI:

(i). fewer patients with digestive disease $(O R=0.295$, 95\% CI = 0.17-0.51);

(ii). fewer patients with $\mathrm{MI}(\mathrm{OR}=0.35,95 \% \mathrm{CI}=0.11-$ $0.91)$ and $\mathrm{DM}(\mathrm{OR}=0.228,95 \% \mathrm{CI}=0.07-0.61)$;

(iii). fewer patients with an altered fat balance $(\mathrm{OR}=0.534,95 \% \mathrm{CI}=0.31-0.93)$;

(iv). more patients below the 10th percentile for weight $(\mathrm{OR}=4.21,95 \% \mathrm{CI}=2.34-7.67)$ and height

$(\mathrm{OR}=1.895,95 \% \mathrm{CI}=1.08-3.34)$;

(v). a higher frequency of $P$. aeruginosa $(\mathrm{OR}=2.495$, $95 \% \mathrm{CI}=1.42-4.48)$ and concurrent mucoid and nonmucoid $P$. aeruginosa $(\mathrm{OR}=3.65,95 \%$ $\mathrm{CI}=2.11-6.38)$;

(vi). a lower frequency of B. cepacia $(\mathrm{OR}=0.302,95 \%$ $\mathrm{CI}=0.09-0.84)$;

(vii). a higher frequency of mixed respiratory disorders $(\mathrm{OR}=17.58,95 \% \mathrm{CI}=4.70-98.87)$ and a lower frequency of restrictive respiratory disorders $(\mathrm{OR}=0.231,95 \% \mathrm{CI}=0.09-0.51)$;

(viii). a lower frequency of moderate and severe SKS $(\mathrm{OR}=0.491,95 \% \mathrm{CI}=0.24-0.96)$ and a higher frequency of excellent and good SKS $(\mathrm{OR}=2.403$; 95\% CI = 1.40-4.16);

(ix). for F508del a heterozygosity mutation was more frequent $(\mathrm{OR}=5.445,95 \% \mathrm{CI}=3.09-9.74)$ in $\mathrm{CF}$ patients with two CFTR mutations screened and less frequent for patients without an identified CFTR mutation $(\mathrm{OR}=0.235,95 \% \mathrm{CI}=0.13-0.42)$; and (x). a higher frequency of patients in preschool $(\mathrm{OR}=2.602,95 \% \mathrm{CI}=1.38-4.94)$ and fewer adult patients $(\mathrm{OR}=0.293,95 \% \mathrm{CI}=0.13-0.60)$.

Figure 2 shows the age at onset of clinical symptoms (Figure 2A) and at diagnosis (Figure 2B).

\section{Discussion}

Evolutionary studies of the clinical and laboratory characteristics of patients with CF have been performed by many organizations worldwide. The Cystic Fibrosis Foundation [17] and the Cystic Fibrosis Trust [18] show the annual records of patients and compare the clinical outcomes in sequential decades. These data allow for appropriate actions by healthcare institutions and government and generate prospects for laboratory and clinical research on CF. However; few studies in Brazil have reported the characteristics of CF annually or in recent decades.

\section{Sex, ethnicity, and consanguinity}

The sex prevalence was equal between the two decades. The disease severity and energy demand are greater both in patients with CF and during puberty, which may result in an increase in the long-term incidence of men with CF [19]. However, this finding was not observed in either DI or DII.

Another finding in this study relates to the prevalence of Caucasian patients with CF. The CF referral center considered is the same in two decades, and the enrolled population comprised patients from the same region; the patients were predominantly Caucasian. In this context, summing the Caucasian prevalence and CF etiology, which is intrinsically of Caucasian patients, values of $>90 \%$ for the Caucasian patients in the two decades was expected.

The prevalence of consanguineous marriage was low at nearly $5 \%$. As a monogenic recessive disease, children of consanguineous parents have a higher risk of developing CF. The public health policy in Brazil helps to lower the risks associated with consanguineous marriages by educating the population about these risks. This policy resulted in a lower number of patients with CF with consanguineous parents in DII than in DI.

\section{Patient age}

Patients in DII were older than those in DI. Age is a factor associated with SKS variability [20] because CF lung disease is associated with a decline in lung function secondary to architectural deterioration of the airways caused by the cycle of inflammation/infection with chronic exacerbations due to bacterial infections [21]. Older patients constitute a major proportion of the 
Table 1 Comparison of data (demographic, clinical, and laboratory markers) of patients with cystic fibrosis from a Brazilian referral center during the decades of 1990 to 2000 and 2000 to 2010

\begin{tabular}{|c|c|c|c|c|}
\hline $\begin{array}{l}\text { Demographic and clinical } \\
\text { markers }\end{array}$ & Category & DI (1990-2000) & DII (2000-2010) & $\mathrm{p}$ \\
\hline Number of patients & & 104 & 181 & \\
\hline \multirow[t]{3}{*}{ Age } & & $\begin{array}{c}\text { Mean: } 10 \text { years } \\
9 \text { months } \pm 6.33 \text { months }\end{array}$ & $\begin{array}{c}\text { Mean :16 years } \\
7 \text { months } \pm 13.16 \text { months }\end{array}$ & $<0.001$ \\
\hline & & Median: 9 years & Median: 12 years 10 months & \\
\hline & & $\begin{array}{l}\text { Range: } 11 \text { months } \\
\text { to } 31 \text { years } 2 \text { months }\end{array}$ & $\begin{array}{l}\text { Range: } 6 \text { months } \\
\text { to } 73 \text { years } 10 \text { months }\end{array}$ & \\
\hline \multirow[t]{2}{*}{ Sex } & Male & $53.8 \%$ & $49.7 \%$ & 0.539 \\
\hline & Female & $46.2 \%$ & $50.3 \%$ & \\
\hline \multirow[t]{2}{*}{ Ethnicity } & Caucasian & $93.3 \%$ & $92.0 \%$ & 0.818 \\
\hline & NonCaucasian & $6.7 \%$ & $8.0 \%$ & \\
\hline Consanguineous parents & & $6.2 \%$ & $1.1 \%$ & 0.054 \\
\hline \multirow[t]{2}{*}{ Manifestation } & Respiratory & $89.4 \%$ & $91.7 \%$ & 0.528 \\
\hline & Digestive & $59.6 \%$ & $83.3 \%$ & $<0.001$ \\
\hline \multirow[t]{3}{*}{ Onset of symptoms } & & Mean: 16 months & Mean: 91.75 months & $<0.001$ \\
\hline & & Median: 3 months & Median: 3 months & \\
\hline & & Range: $0-20$ years & Range: $0-60$ years & \\
\hline \multirow[t]{3}{*}{ Age at diagnosis } & & Mean: 4 years 2 months & Mean: 2 years 10 months & $<0.001$ \\
\hline & & Median: 2 years 4 months & Median: 2 years & \\
\hline & & $\begin{array}{c}\text { Range: } 0 \text { to } 29 \text { years } \\
11 \text { months }\end{array}$ & Range: $0-60$ years & \\
\hline Meconium ileus & & $5.8 \%$ & $15.0 \%$ & 0.021 \\
\hline Diabetes mellitus & & $4.8 \%$ & $18.5 \%$ & 0.001 \\
\hline \multirow[t]{2}{*}{ Nutritional status } & Weight below 10th percentile & $69.9 \%$ & $35.71 \%$ & $<0.001$ \\
\hline & Height below 10th percentile & $56.6 \%$ & $40.82 \%$ & 0.025 \\
\hline \multirow[t]{3}{*}{$\mathrm{SpO}_{2}$} & $>95 \%$ & $59.5 \%$ & $55.5 \%$ & 0.713 \\
\hline & $91 \%-95 \%$ & $32.9 \%$ & $34.7 \%$ & \\
\hline & $<91 \%$ & $7.6 \%$ & $9.8 \%$ & \\
\hline \multirow[t]{3}{*}{ Sweat test } & $<60 \mathrm{mEq} / \mathrm{L}^{*}$ & $10.6 \%$ & - & \\
\hline & 60-100 mEq/L & $28.8 \%$ & $40.51 \%$ & \\
\hline & $>100 \mathrm{mEq} / \mathrm{L}$ & $60.6 \%$ & $59.49 \%$ & \\
\hline \multirow[t]{5}{*}{ Bacteria } & Staphylococcus aureus & $80.2 \%$ & $78.5 \%$ & 0.880 \\
\hline & Pseudomonas aeruginosa & $76.0 \%$ & $55.8 \%$ & 0.001 \\
\hline & Mucoid $P$. aeruginosa & $53.1 \%$ & $42.0 \%$ & 0.085 \\
\hline & Burkholderia cepacia & $5.2 \%$ & $14.4 \%$ & 0.016 \\
\hline & Mucoid and nonmucoid $P$. aeruginosa & $51.0 \%$ & $21.85 \%$ & $<0.001$ \\
\hline \multirow[t]{4}{*}{ Spirometry } & Normal & $27.3 \%$ & $34.4 \%$ & $<0.001$ \\
\hline & Restrictive ventilatory disorder & $18.2 \%$ & $48.9 \%$ & \\
\hline & Obstructive lung disorder & $25.4 \%$ & $14.5 \%$ & \\
\hline & Mixed respiratory disorder & $29.1 \%$ & $2.3 \%$ & \\
\hline \multirow[t]{5}{*}{ CFTR mutation } & F508del homozygotes & $18.75 \%$ & $26.5 \%$ & $<0.001$ \\
\hline & F508del heterozygotes & $62.5 \%$ & $22.7 \%$ & \\
\hline & G542X & $4.17 \%$ & $6.45 \%$ & \\
\hline & N1303K & $2.08 \%$ & $1.1 \%$ & \\
\hline & G551D & $1.04 \%$ & - & \\
\hline
\end{tabular}


Table 1 Comparison of data (demographic, clinical, and laboratory markers) of patients with cystic fibrosis from a Brazilian referral center during the decades of 1990 to 2000 and 2000 to 2010 (Continued)

\begin{tabular}{|c|c|c|c|c|}
\hline \multirow{5}{*}{$\begin{array}{l}\text { Shwachman-Kulczycki } \\
\text { score }\end{array}$} & R553X & $0.52 \%$ & $0.3 \%$ & \multirow{5}{*}{0.005} \\
\hline & W1282X & $0.52 \%$ & - & \\
\hline & Excellent or good & $57.8 \%$ & $36.2 \%$ & \\
\hline & Mild & $26.5 \%$ & $36.2 \%$ & \\
\hline & Moderate or severe & $15.7 \%$ & $27.6 \%$ & \\
\hline Deaths & & 18 & 31 & 1 \\
\hline Fecal balance & & $67.9 \%$ & $80.0 \%$ & 0.031 \\
\hline
\end{tabular}

$\mathrm{DI}$ - period from 1990 to 2000; DII - period from 2000 to 2010; SpO - transcutaneous hemoglobin saturation by oxygen; $\mathrm{p}$ - p-value. Statistical analysis was performed by the $x^{2}$ test. Statistically significant values are indicated by bold font. *Patients with two identified CFTR mutations.

patients seen at $\mathrm{CF}$ centers, and older age can be associated with variations in $\mathrm{CF}$ diagnosis and treatment [22].

Digestive disease, $\mathrm{PI}$, and fecal balance

An important finding is that the digestive symptoms exhibited the same frequency between the two decades. Digestive symptoms are often the first clinical marker of classic CF and are reported in 95\% of patients with classic CF. Because no change in prevalence was observed, this marker continues to be a target for first-line treatment of patients with CF. After initial treatment, the severity of symptoms and progression of lung disease decrease.

The specific digestive symptoms associated with the severity of CF are PI, DM, and MI. Among these digestive symptoms, the principal marker of CF is PI. A

Table 2 Presence of digestive symptoms, comorbidities, and percentiles for weight and height in patients with cystic fibrosis in a Brazilian referral center during the decades of 1990 to 2000 and 2000 to 2010

\begin{tabular}{|c|c|c|c|c|c|c|}
\hline \multirow[t]{2}{*}{ Decade } & \multicolumn{3}{|c|}{ Onset of digestive symptoms } & \multirow[t]{2}{*}{$p$-value } & \multirow[t]{2}{*}{ OR } & \multirow[t]{2}{*}{$95 \% \mathrm{Cl}$} \\
\hline & Presence & Absence & Total & & & \\
\hline 1990-2000 & $62(59.6 \%)$ & $42(40.4 \%)$ & 104 & $<0.001$ & 0.295 & $0.17-0.51$ \\
\hline $2000-2010$ & $151(83.4 \%)$ & $30(16.6 \%)$ & 181 & & 1 & - \\
\hline \multirow[t]{2}{*}{ Decade } & \multicolumn{3}{|c|}{ Meconium ileus } & $p$ & OR & $95 \% \mathrm{Cl}$ \\
\hline & Presence & Absence & Total & & & \\
\hline 1990-2000 & $6(5.8 \%)$ & $98(94.2 \%)$ & 104 & 0.021 & 0.35 & $0.11-0.91$ \\
\hline 2000-2010 & $27(14.9 \%)$ & & 181 & & 1 & - \\
\hline \multirow[t]{2}{*}{ Decade } & \multicolumn{3}{|c|}{ Diabetes mellitus } & $p$ & OR & $95 \% \mathrm{Cl}$ \\
\hline & Presence & Absence & Total & & & \\
\hline 1990-2000 & $5(4.8 \%)$ & 99 (95.2\%) & 104 & 0.001 & 0.228 & $0.07-0.61$ \\
\hline 2000-2010 & $33(18.2 \%)$ & $148(81.8 \%)$ & 181 & & 1 & - \\
\hline \multirow[t]{2}{*}{ Decade } & \multicolumn{3}{|c|}{ Fecal fat balance } & $p$ & $\mathrm{OR}$ & $95 \% \mathrm{Cl}$ \\
\hline & Presence & Absence & Total & & & \\
\hline 1990-2000 & 71 (68.3\%) & $33(31.7 \%)$ & 104 & 0.031 & 0.534 & $(0.31-0.93)$ \\
\hline 2000-2010 & $145(80.1 \%)$ & 36 (24.2\%) & 181 & & 1 & - \\
\hline \multirow[t]{2}{*}{ Decade } & \multicolumn{3}{|c|}{ Weight percentile } & $p$ & OR & $95 \% \mathrm{Cl}$ \\
\hline & $P<10$ & $P \geq 10$ & Total & & & \\
\hline 1990-2000 & $73(70.2 \%)$ & $31(29.8 \%)$ & 104 & $<0.001$ & 4.206 & $2.34-7.67$ \\
\hline 2000-2010 & 35 (35.9\%) & $63(64.1 \%)$ & 98 & & 1 & - \\
\hline \multirow[t]{2}{*}{ Decade } & \multicolumn{3}{|c|}{ Height percentile } & $p$ & OR & $95 \% \mathrm{Cl}$ \\
\hline & $P<10$ & $P \geq 10$ & Total & & & \\
\hline 1990-2000 & 59 (56.7\%) & $45(43.3 \%)$ & 104 & 0.025 & 1.895 & $1.08-3.34$ \\
\hline 2000-2010 & 40 (40.9\%) & $58(59.1 \%)$ & 98 & & 1 & - \\
\hline
\end{tabular}

$\mathrm{P}$ - percentile; $\mathrm{p}$ - p-value; $\mathrm{OR}$ - odds ratio; $\mathrm{Cl}$ - confidence interval. Statistical analysis was performed by the $\mathrm{X}^{2}$ test. Statistically significant values are indicated by bold font. 
Table 3 Presence of bacteria in sputum samples of patients with cystic fibrosis in a Brazilian referral center during the decades of 1990 to 2000 and 2000 to 2010

\begin{tabular}{|c|c|c|c|c|c|c|}
\hline \multirow[t]{2}{*}{ Decade } & \multicolumn{3}{|c|}{ Pseudomonas aeruginosa* } & \multirow[t]{2}{*}{ p-value } & \multirow[t]{2}{*}{ OR } & \multirow[t]{2}{*}{$95 \% \mathrm{Cl}$} \\
\hline & Presence & Absence & Total & & & \\
\hline 1990-2000 & 79 (76.0\%) & $25(24.0 \%)$ & 104 & 0.001 & 2.495 & $1.42-4.48$ \\
\hline 2000-2010 & $101(55.8 \%)$ & $80(44.2 \%)$ & 181 & & 1 & - \\
\hline \multirow[t]{2}{*}{ Decade } & \multicolumn{3}{|c|}{ Burkholderia cepacia } & $\mathrm{p}$-value & OR & $95 \% \mathrm{Cl}$ \\
\hline & Presence & Absence & Total & & & \\
\hline 1990-2000 & $5(4.8 \%)$ & 99 (95.2\%) & 104 & 0.016 & 0.302 & $0.09-0.84$ \\
\hline 2000-2010 & $26(14.4 \%)$ & $155(85.6 \%)$ & 181 & & 1 & - \\
\hline \multirow[t]{2}{*}{ Decade } & \multicolumn{3}{|c|}{ Mucoid and nonmucoid $P$. aeruginosa ${ }^{\#}$} & $p$-value & $\mathrm{OR}$ & $95 \% \mathrm{Cl}$ \\
\hline & Presence & Absence & Total & & & \\
\hline 1990-2000 & $53(51.0 \%)$ & $51(49.0 \%)$ & 104 & $<0.001$ & 3.645 & $2.11-6.38$ \\
\hline 2000-2010 & 40 (22.1\%) & 141 (77.9\%) & 181 & & 1 & - \\
\hline
\end{tabular}

$\mathrm{OR}$ - odds ratio; $\mathrm{Cl}$ - confidence interval. Statistical analysis was performed by the $\mathrm{X}^{2}$ test. Statistically significant values are indicated by bold font. *Analysis considering the presence of nonmucoid P. aeruginosa isolated in culture. ${ }^{\# A n a l y s i s ~ c o n s i d e r i n g ~ t h e ~ s i m u l t a n e o u s ~ p r e s e n c e ~ o f ~ m u c o i d ~ a n d ~ n o n m u c o i d ~} P$. aeruginosa.

diagnosis of PI was more prevalent in DI than in DII in this study. PI is principally associated with severe CFTR mutations and, secondarily, with modifier genes [23]. PI screening was performed by fecal fat and/or fecal elastase testing. Because no change in the diligence of PI screening occurred in our center during the two decades, we believe that the decreased frequency of PI with time can be explained by the inclusion of patients with mild CF.

\section{Diagnosis and nutrition status}

Patients with CF have better clinical outcomes when diagnosed earlier [24]. This fact was highlighted in the comparison of DI and DII; both earlier diagnosis and improved clinical outcomes were noted in DII. In Brazil, the creation of the Brazilian Cystic Fibrosis Study Group and the establishment of referral centers have favored wider dissemination of CF screening guidelines. These facts contributed to the shorter diagnosis time in DII. We found that in patients with severe CR, the diagnosis time did not differ between DI and DII. For patients with less severe CF, however, the diagnosis time was shorter in DII than in DI (this was only seen as a difference between the mean diagnosis times, not the median).

Early diagnosis and IRT screening are associated with each other in patients with CF [25]. In the two decades of the present study, however, IRT screening was not used in our center. IRT screening was implemented in our state at the end of the second decade (2010) and in the entire country in 2014. Thus, we hope that in the next decade, patients with $\mathrm{CF}$ will receive a diagnosis in the first few months of life and that the clinical features of CF will continue to improve with earlier intervention.

Patients with CF who maintain normal growth in the first 2 years of diagnosis show better lung function, less coughing, and better chest radiographs at 6 years of age. The benefits of IRT screening for pulmonary status at 6 years of age depend on the initial nutritional status and are strongly associated with the need for comprehensive and consistent treatment implemented immediately after diagnosis [26,27]. In the present study, earlier diagnosis in DII seemed to influence the nutritional status. There were fewer patients with CF below the 10th percentile for weight and height.

\section{Comorbidities: DM and MI}

The prevalence of DM was $4.8 \%$ in DI and $18.5 \%$ in DII. This comorbidity is related to increased patient age, the arising of modifier genes [28] secondary to the inflammatory process, and consecutive destruction of the exocrine pancreas [29]. The severity of CF was greater in female than in male patients, especially during adolescence [30]. Patients with concurrent CF and DM have severe pulmonary disease with a higher prevalence of pathogens in the sputum, malnutrition, an increased incidence of liver disease, and increased mortality rates [30]. The recent increase in life expectancy for patients with CF has caused an increase in the prevalence of DM, and the mortality rates for these patients remain high [31].

The prevalence of MI was lower in DI than in DII; the prevalence in each decade was close to that cited in the literature (14\% and $11 \%$, respectively) [32]. This probably occurred because in DI, patients with concurrent CF and $\mathrm{MI}$ died in the first year of life, before the diagnosis of CF was confirmed [13,33].

\section{Spirometry and lung disease}

One of the most important markers of CF severity is the decline in spirometry values throughout life, as more than $90 \%$ of patients with CF die of lung disease. This 
Table 4 Spirometry, Shwachman-Kulczycki scores, and prevalence of F508del mutation in patients with cystic fibrosis in a Brazilian referral center during the decades of 1990 to 2000 and 2000 to 2010

\begin{tabular}{|c|c|c|c|c|c|c|c|c|c|}
\hline \multirow[t]{2}{*}{ Decade } & \multicolumn{8}{|c|}{ Spirometry } & \multirow[t]{2}{*}{ Total } \\
\hline & ORD & OR $(95 \% \mathrm{Cl})$ & MRD & OR $(95 \% \mathrm{Cl})$ & RVD & OR $(95 \% \mathrm{Cl})$ & Normal & OR $(95 \% \mathrm{Cl})$ & \\
\hline 1990-2000 & $14(25.0 \%)$ & $2.058(0.87-4.79)$ & $16(29.8 \%)$ & $17.58(4.70-98.97)$ & $10(18.3 \%)$ & $0.231(0.10-0.51)$ & 15 (26.9\%) & $0.719(0.33-1.50)$ & 55 \\
\hline 2000-2010 & $19(14.2 \%)$ & 1 & $3(2.2 \%)$ & 1 & $66(49.3 \%)$ & 1 & $46(34.3 \%)$ & 1 & 134 \\
\hline \multirow[t]{2}{*}{ Decade } & \multicolumn{8}{|c|}{ Clinical score } & \multirow[t]{2}{*}{ Total } \\
\hline & Moderate/Severe & \multicolumn{2}{|c|}{ OR $(95 \% \mathrm{Cl})$} & Mild & OR (95\% Cl) & \multicolumn{2}{|c|}{ Excellent/Good } & OR $(95 \% \mathrm{Cl})$ & \\
\hline 1990-2000 & $13(15.4 \%)$ & \multicolumn{2}{|c|}{$0.491(0.24-0.96)$} & $22(26.9 \%)$ & $0.635(0.34-1.18)$ & \multicolumn{2}{|c|}{$48(57.7 \%)$} & $2.403(1.40-4.16)$ & 83 \\
\hline 2000-2010 & $44(27.5 \%)$ & \multicolumn{2}{|l|}{1} & $58(36.3 \%)$ & 1 & \multicolumn{2}{|c|}{$58(36.3 \%)$} & 1 & 160 \\
\hline \multirow[t]{2}{*}{ Decade } & \multicolumn{8}{|c|}{ F508del mutation genotype } & \multirow[t]{2}{*}{ Total } \\
\hline & Homozygotes & \multicolumn{2}{|c|}{ OR $(95 \% \mathrm{Cl})$} & Heterozygotes & OR $(95 \% \mathrm{Cl})$ & \multicolumn{2}{|c|}{ Without F508del } & OR $(95 \% \mathrm{Cl})$ & \\
\hline 1990-2000 & $19(20.2 \%)$ & \multicolumn{2}{|c|}{$0.647(0.34-1.21)$} & $59(61.5 \%)$ & 5.445 (3.09-9.74) & \multicolumn{2}{|c|}{$18(18.3 \%)$} & $0.235(0.13-0.42)$ & 96 \\
\hline 2000-2010 & 50 (27.6\%) & \multicolumn{2}{|l|}{1} & 41 (22.7\%) & 1 & \multicolumn{2}{|c|}{90 (49.7\%) } & 1 & 181 \\
\hline
\end{tabular}

OR - odds ratio; $\mathrm{Cl}$ - confidence interval; ORD - obstructive respiratory disorder; MRD - mixed respiratory disorder; RVD - restrictive ventilatory disorder. Statistical analysis was performed by the $\mathrm{X}^{2}$ test. Statistically significant values are indicated by bold text. 
Table 5 Analysis of age of patients with cystic fibrosis in a Brazilian referral center during the decades of 1990 to 2000 and 2000 to 2010

\begin{tabular}{|c|c|c|c|c|}
\hline \multirow{2}{*}{$\begin{array}{l}\text { Age } \\
\text { groups }\end{array}$} & \multicolumn{2}{|c|}{ Decades } & \multirow[t]{2}{*}{$p$-value } & \multirow[t]{2}{*}{ OR $(95 \% \mathrm{Cl})$} \\
\hline & 1990-2000 & $2000-2010$ & & \\
\hline Newborn & $0(0.0 \%)$ & $0(0.0 \%)$ & $<0.001$ & - \\
\hline Infant & $6(7.0 \%)$ & $6(3.4 \%)$ & & $2.131(0.63-7.19)$ \\
\hline Preschool & 25 (29.1\%) & 24 (13.6\%) & & $2.602(1.38-4.94)$ \\
\hline Academic & $18(20.9 \%)$ & 52 (29.4\%) & & $0.636(0.35-1.17)$ \\
\hline Adolescent & 27 (31.4\%) & 40 (22.6\%) & & $1.567(0.88-2.79)$ \\
\hline Adult & $10(11.6 \%)$ & 55 (31.0\%) & & $0.293(0.13-0.60)$ \\
\hline
\end{tabular}

$\mathrm{OR}$ - odds ratio; $\mathrm{Cl}$ - confidence interval. Statistical analysis was performed by the $x^{2}$ test. Statistically significant values are indicated by bold text.

decline in lung function varies with the presence of CFTR mutation, age at diagnosis, presence of PI, environmental pollution, nutritional status, adherence to treatment, comorbidities (DM, depression, osteopenia, and chronic infection), and sex. Airway changes caused by CF first affect the small airways, followed by the larger airways and finally the pulmonary parenchyma. The instruments used to measure pulmonary function have different sensitivities and specificities. However, spirometry is widely used to document longitudinal changes because it is both inexpensive and noninvasive. A reduction in the incidence of obstructive lung disease and an increase in the incidence of restrictive disorders was observed as time progressed from DI to DII. CF is primarily an obstructive lung disease, as observed in DI [34], while restrictive disorders were more prevalent in DII. Patients with class I, II, and III CFTR mutations have a worse prognosis; however, with aggressive treatment they can experience prolonged survival despite lower lung function. No difference was observed in the $\mathrm{SpO}_{2}$ in this study.

\section{Sweat chloride concentration}

Measurement of the sweat chloride concentration by the Gibson and Cooke method [35] is the gold standard for a diagnosis of CF. Values of $>60 \mathrm{mEq} / \mathrm{L}$ are indicative of CF. In DI, $10.6 \%, 28.8 \%$, and $60.6 \%$ of patients had a sweat chloride concentration of 40 to 60,60 to 100 , and $>100 \mathrm{mEq} / \mathrm{L}$, respectively. In DII, all patients with CF had sweat chloride concentrations of $>60 \mathrm{mEq} / \mathrm{L}$. Patients with sweat chloride concentrations of $<60 \mathrm{mEq} / \mathrm{L}$ in DI had other diagnostic criteria for $\mathrm{CF}$ such as respiratory and digestive symptoms compatible with $\mathrm{CF}$, colonization by $P$. aeruginosa, and, principally, F508del mutation.

A difficult clinical problem is the assessment of individuals with signs and symptoms of CF but borderline sweat chloride concentrations. The diagnosis of CF can be clarified by evaporimetry, electrophysiology of epithelial tissues (measurement of the nasal potential difference and evaluation of the digestive epithelium using rectal biopsy or an Ussing chamber), and CFTR mutation screening in patients with signs and symptoms of CF, but with normal sweat test results [36-38].

\section{Microorganisms}

In patients with CF, morbidity and mortality are associated with chronic bronchial infection by various pathogens [36]. Recent evidence suggests that the presence of such microorganisms along with opportunistic pathogens can affect the infection course and outcome [39]. No changes in the microbiologic profile of airway secretions in patients with nonmucoid and mucoid $P$. aeruginosa infection were observed between DI and DII. The main factors associated with chronic colonization or infection of airways by these bacteria in patients with $\mathrm{CF}$ are environmental contamination, rigorous treatment for the first colonization, screening diligence, increasing age, and genetic modulation $[40,41]$. There was a higher frequency of B. cepacia isolation in sputum from the patients in DII. This finding may suggest that the environmental prophylaxis adopted in our center is not appropriate because it indicates cross-contamination among patients. Additionally, this increase may be due to the use of better screening tools in our diagnostic routine (specific polymerase chain reaction for $B$. cepacia). These facts may also account for the increased frequency of Achromobacter xylosoxidans isolation in DII. Thus, increasing patient age and diligence for B. cepacia identification by specific means must have been responsible for the higher rates of colonization and infection in DII.

\section{CFTR genotype}

Currently, patients with CF can be divided into two groups using IRT screening: those with classic CF with class I, II, and III mutations who reach adulthood because they have received pediatric care, and those with CF caused by class IV, V, and VI mutations whose symptoms began in adolescence or adulthood.

Physicians who care for adults must consider these two groups of patients with CF because they have different genotypes and phenotypes. Future studies should assess and share the developments and clinical and laboratory characteristics of these groups as patients with typical and atypical CF. It is expected that patients with classic CF will develop impaired lung function in childhood and exhibit a serious decline in function until adulthood, while the same does not happen for patients with CF with mild mutations, in whom lung function values may be normal or near normal and who exhibit only a mild to moderate decline in function over their lifetime.

The most frequent CFTR mutations in this Brazilian population differed between the two decades studied. A 


\begin{tabular}{|c|c|}
\hline \multirow{2}{*}{ Variable } & Clinical response \\
\hline & $1990-2000$ \\
\hline Age & Better treatment and early diagnostic \\
\hline Sex & Equal $=$ autosome recessive disease \\
\hline Ethnicity & Same Caucasian origin \\
\hline Consanguineous & Reduction associated with better knowledge and increased population \\
\hline Respiratory & Principally clinical outcome \\
\hline Digestive & Patients with higher life expectancy shows bigger digestive disorder \\
\hline Symptoms onset & Early diagnostic and better management \\
\hline Diagnostic & $\begin{array}{l}\text { Early diagnostic performed associated with better knowledge of the disease } \\
\text { and reference center dissemination }\end{array}$ \\
\hline Meconium ileus & High life expectancy and better management of newborns with meconium ileus \\
\hline Diabetes mellitus & High life expectancy \\
\hline Weight & High life expectancy of patients with severe disease \\
\hline Height & High life expectancy of patients with severe disease \\
\hline $\mathrm{SpO} 2$ & Similar values $=$ spirometry shows early difference \\
\hline Sweat test & Standard values not difference between the populations \\
\hline S. aureus & High frequency is a normal data on cystic fibrosis \\
\hline P. aeruginosa & Better antibiotic therapy associated with clinical and laboratory investigation \\
\hline B. cepacia & High frequency possible associated with better investigation and cross infection disease \\
\hline $\begin{array}{c}\mathrm{M} \text { and } \mathrm{NM} P . \\
\text { aeruginosa }\end{array}$ & Better antibiotic therapy with clinical and laboratory investigation \\
\hline Spirometry & $\begin{array}{l}\begin{array}{l}\text { Restrictive disease associated with lung degradation secondarily of previous obstructive } \\
\text { disease }\end{array}\end{array}$ \\
\hline CFTR mutation & $\begin{array}{l}\text { Bigger heterozygosis and F508del mutation with high homozygotes prevalence = } \\
\text { patients with worst disease can have bigger life expectancy }\end{array}$ \\
\hline SK score & Worst values associated with older patients \\
\hline Deaths & No proportional difference \\
\hline Fat fecal balance & $\begin{array}{l}\text { Bigger values associated with the better life expectancy of patients with severe } \\
\text { disease }\end{array}$ \\
\hline & No statistical difference between the two decades \\
\hline \multicolumn{2}{|r|}{ Positive clinical outcome in the second decade } \\
\hline \multicolumn{2}{|r|}{ Negative clinical outcome in the second decade } \\
\hline
\end{tabular}

Figure 1 Clinical outcome variables the between two decades of data for patients with cystic fibrosis from a Brazilian referral center. $\mathrm{SpO}_{2}$ - transcutaneous hemoglobin saturation by oxygen; SKS, - Shwachman-Kulczycki score; M and NM, - mucoid and nonmucoid.

higher prevalence of homozygous mutations and a lower prevalence of the heterozygous forms of the F508del mutation were observed in DII. Additionally, a higher number of compound heterozygotes, but without screening of the second mutation, was observed in DII. The failure to identify the second mutation in a large group of patients, even when the diagnosis of CF was clinically established and confirmed by two chloride level readings of $>60 \mathrm{mEq} /$ $\mathrm{L}$, makes comparison between the two decades difficult.

Two aspects of diagnosis that should be emphasized are the use of F508del screening as the first step in CFTR mutation screening [42] and the need for greater attention on patients with CF diagnosed in adulthood [43] than in pediatric patients with CF [44]. 

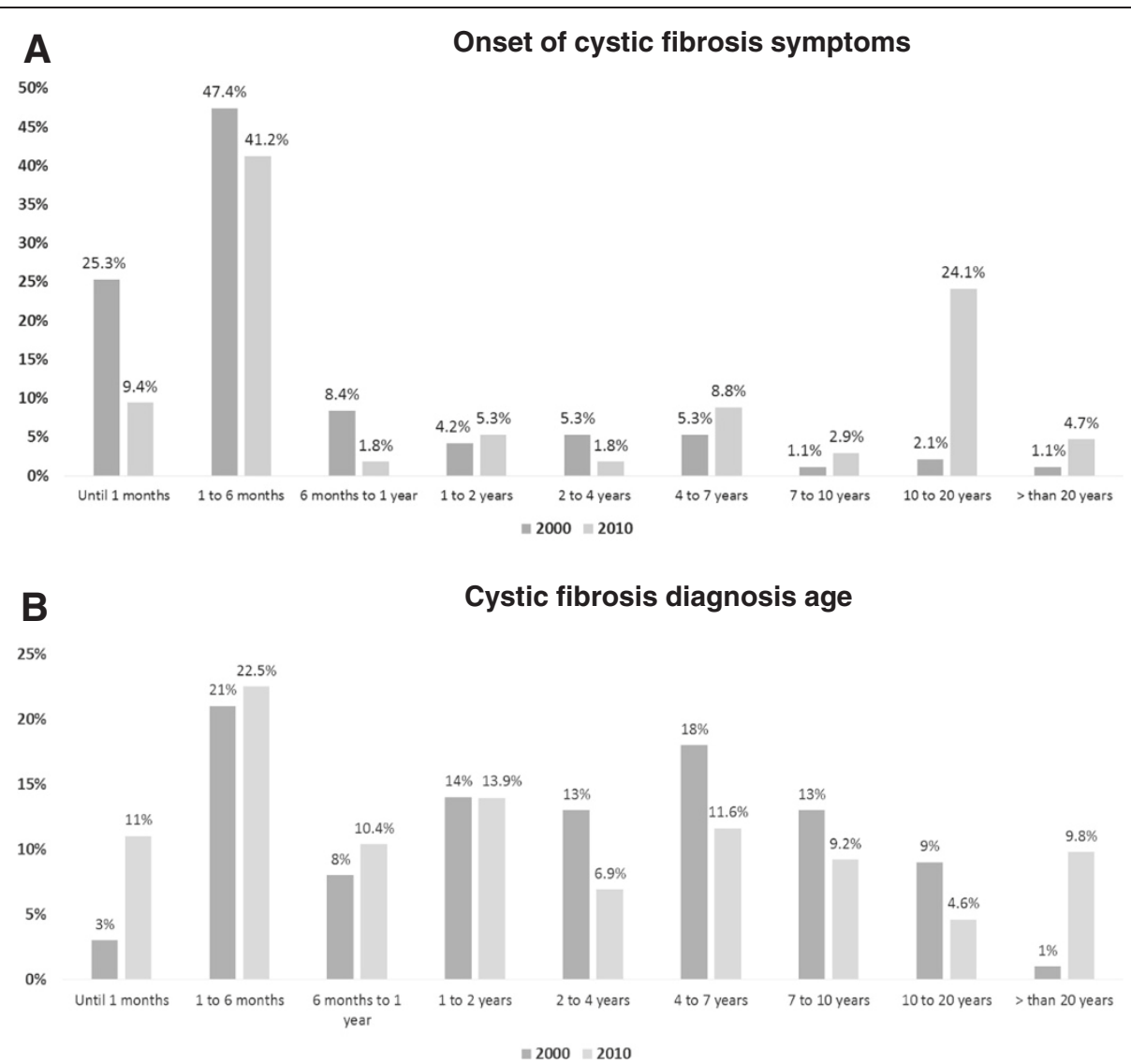

Figure 2 Distribution of patients with cystic fibrosis according to ages at onset of symptoms and diagnosis. A. Comparison of the distribution of patients with cystic fibrosis according to age at onset of symptoms between decades I $(n=95)$ and II ( $n=181)$. B. Comparison of distribution of patients with cystic fibrosis according to age at diagnosis between decades I $(n=100)$ and II $(n=180)$.

\section{Clinical score}

The SKS measures clinical severity with consideration of physical activity, radiographic findings, nutritional status, and physical examination findings [15]. This scoring system was created for children, but continues to be applied to patients with CF of all ages. Scores are undoubtedly needed for both children and adults covering all SKS characteristics. There were fewer excellent/good scores and more moderate/severe scores in DII than in DI. Similar to the results of the other analyses between these two decades, this finding can be explained because we are leading with the same population with class I, II, and III mutations whose symptoms appear early in childhood and who exhibit worsening of clinical and laboratory outcomes until the beginning of adulthood.

\section{CF outcome-related death}

There were 18 and 31 deaths in DI and DII, respectively. There was no statistically significant difference in the number of deaths between the two decades. The increase in the number of deaths from DI to DII was proportional to the increase in the number of patients seen from DI to DII.

\section{Study overview}

From DI to DII in our center, the management, interdisciplinary team, and conditions for CF diagnosis did not change significantly. The fewer bacterial infections and better nutrition in DII than in DI indicate the evolution and importance of early diagnosis and management of CF. These advancements provide patients with more hope and a higher quality of life. Although many differences between the two decades were related to the earlier diagnosis in DII, the changes in some variables reflect the association between the severity of $\mathrm{CF}$ and the aging process, such as the worsening SKS.

The implementation of IRT screening in our state was confirmed at the end of DII. In the next decade, this will likely prove to be an important milestone on par with the discovery of the CFTR gene in the late 1980s. Many professionals currently working with patients with CF in Brazil are participating in the implementation of the national IRT screening program. There are great expectations 
regarding the future benefits of early diagnosis of $\mathrm{CF}$ on the health of both pediatric and adult Brazilian patients. With time, new questions will emerge in the treatment and management of patients with this intriguing pathophysiological condition [45].

\section{Study limitations}

The patients' records provided limited information in some cases. Complete CFTR screening was not performed in all patients with CF enrolled in the study. In DI, it was not possible to collect information about the medications used. Only one CF referral center was included in the data, and inclusion of other centers was not possible because of the lack of information and mixed population from our state. Numerical data for spirometry, weight, height, $\mathrm{SpO}_{2}$, and SKS were completely recovered only for DII; thus, we were unable to perform statistical tests for numerical variables. Only one clinical score was obtained in DI.

\section{Conclusion}

The clinical outcomes of CF changed from DI to DII in our referral center. Demographic, clinical, and laboratory analyses of patients with CF are useful and should be encouraged in referral centers worldwide. This will provide information on the clinical evolution of CF according newly available diagnostic tools, treatments, and management protocols. Furthermore, new studies on the complex features of CF will provide better knowledge of the disease. The outcomes of early diagnosis and management should be evaluated to provide a better quality of life and longer life expectancy until a personalized drug therapy is available for all CFTR class mutations. Each day we take steps toward better clinical outcomes for patients with CF, a pediatric disease with high mortality in some cases and an adult lung disease in other cases with better outcomes when diagnosis is performed early in life. We will continue our studies to achieve a cure for $\mathrm{CF}$.

\section{Abbreviations \\ CF: Cystic fibrosis; CFTR: Cystic fibrosis transmembrane regulator gene; IRT: Immunoreactive trypsinogen; DI: First decade; DII: Second decade; SKS: Shwachman-Kulczycki score; Pl: Pancreatic insufficiency; MI: Meconium ileus; DM: Diabetes mellitus; $\mathrm{SpO}_{2}$ : Oxygen saturation; $\mathrm{FEV}_{1}$ : Forced expiratory volume in the first second; FVC: Forced vital capacity; OR: Odds ratio; 95\% Cl: 95\% confidence interval.}

\section{Competing interests}

The authors declare that they have no competing interests.

\section{Authors' contributions}

FALM, TDRH, KCCA, and JDR conceptualized and designed the study; drafted, reviewed, and revised the manuscript; and approved the final manuscript as submitted. The CYFIUC Group collected the data.

\section{Authors' information}

CYFIUC (Cystic Fibrosis Unicamp Center) Group: Carmen Silvia Bertuzzo, Antonio Fernando Ribeiro, Adyleia Dalbo Contrera Toro, Roberto Jose
Negrao Nogueira, Gabriel Hessel, Carlos Emilio Levy, Maria Angela Gonçalves de Oliveira Ribeiro, Eulalia Sakano, Maria de Fatima Servidoni, Monica Corso Pereira, Ilma Aparecida Paschoal, Paloma Lopes Francisco Parazzi, Camila Izabel Santos Schivinski, Renata Tiemi Okuro, Luciana Cardoso Bonadia, Alfonso Eduardo Alvarez, Silvana Dalge Severino, Andressa Peixoto, Carla Cristina Souza Gomez.

\section{Acknowledgements}

We thank the Laboratory of Medical Genetics (www.laboratoriomultiusuario. com.br) for performing the analysis and screening of CFTR mutations and LAFIP/CIPED by analysis of spirometry. Financial support was provided by FAPESP (FALM: 2011/12939-4), FAEPEX - Unicamp, CNPq, and CAPES.

Received: 6 August 2013 Accepted: 6 January 2015

Published: 15 January 2015

\section{References}

1. Riordan JR, Rommens JM, Kerem B, Alon N, Rozmahel R, Grzelczak Z, et al. Identification of the cystic fibrosis gene: cloning and characterization of the complementary DNA. Science. 1989;245:1066-73.

2. Kerem BS, Rommens JM, Buchanan JA, Markiewicz D, Cox TK, Chakravarti A, et al. Identification of the cystic fibrosis gene: genetic analysis. Science. 1989;245:1073-80.

3. Rommens JM, lannuzzi MC, Kerem BS, Drumm ML, Melmer G, Dean M, et al. Identification of the cystic fibrosis gene: chromosome walking and jumping. Science. 1989:245:1059-65.

4. Clinical and Functional Translation of CFTR. http://www.cftr2.org/.

5. NCBI Gene: CFTR cystic fibrosis transmembrane conductance regulator (ATP-binding cassette sub-family C, member 7) [Homo sapiens (human)]. [http://www.ncbi.nlm.nih.gov/gene/1080].

6. Cystic Fibrosis Mutation Database. http://www.genet.sickkids.on.ca/app.

7. Farrell PM, Rosenstein BJ, White TB, Accurso FJ, Castellani C, Cutting GR, et al. Cystic Fibrosis Foundation: Cystic Fibrosis Foundation. Guidelines for diagnosis of cystic fibrosis in newborns through older adults: Cystic Fibrosis Foundation consensus report. J Pediatr. 2008;153:S4-S14.

8. Rowe SM, Miller S, Sorscher EJ. Mechanisms of disease: cystic fibrosis. N Engl J Med. 2005;352:1992-2001.

9. Fanen P, Wohlhuter-Haddad A, Hinzpeter A. Genetics of cystic fibrosis: CFTR mutation classifications toward genotype-based CF therapies. Int J Biochem Cell Biol. 2014;52:94-102.

10. Vallières E, Elborn JS. Cystic fibrosis gene mutations: evaluation and assessment of disease severity. Adv Genomics Genet. 2014;4:161-72.

11. McKone EF, Borowitz D, Drevinek P, Griese M, Konstan MW, Wainwright C, et al. Long-term safety and efficacy of ivacaftor in patients with cystic fibrosis who have the Gly551Asp-CFTR mutation: a phase 3, open-label extension study (PERSIST). Lancet Respir Med. 2014;S2213-2600(14):902-10.

12. Agent $P$, Morison $L$, Prasad A. Standards for the clinical care of children and adults with cystic fibrosis in the UK - second edition. In: Cystic Fibrosis Trust. 2011. p. 1-46.

13. Alvarez AE, Ribeiro AF, Hessel G, Bertuzzo CS, Ribeiro JD. Cystic fibrosis at a Brazilian center of excellence: clinical and laboratory characteristics of 104 patients and their association with genotype and disease severity. J Pediatr (Rio J). 2004:80:371-9.

14. American Thoracic Society (ATS). http://www.thoracic.org/.

15. Santos CIS, Ribeiro JD, Ribeiro AF, Hessel G. Critical analysis of scoring systems used in the assessment of Cystic Fibrosis severity: state of the art. J Bras Pneumol. 2004:30:286-98.

16. SPSS 21.0 for Windows (computer program). Statistical Package for Social Science (SPSS). Release Version 21.0 Chicago (IL): SPSS. Incorporation; 2013 [http://www.spss.com]

17. Cystic Fibrosis Foundation. www.cff.org.

18. Cystic Fibrosis Trust. [www.cftrust.org.uk].

19. Sims EJ, Green MW, Mehta A. Decreased lung function in female but not male subjects with established cystic fibrosis-related diabetes. Diabetes Care. 2005;28:1381-7.

20. Anjorin A, Schmidt H, Posselt HG, Smaczny C, Ackermann H, Deimling M, et al. Comparative evaluation of chest radiography, low-field MRI, the Shwachman-Kulczycki score and pulmonary function tests in patients with cystic fibrosis. Eur Radiol. 2008;18:1153-61.

21. Davies JC, Alton EW. Monitoring respiratory disease severity in cystic fibrosis. Respir Care. 2009;54:606-17. 
22. Mishra A, Greaves R, Smith K, Carlin JB, Wootton A, Stirling R, et al. Diagnosis of cystic fibrosis by sweat testing: age-specific reference intervals. J Pediatr. 2008;153:758-63.

23. Drumm ML, Ziady AG, Davis PB. Genetic variation and clinical heterogeneity in cystic fibrosis. Annu Rev Pathol. 2012;7:267-82.

24. Rosenfeld M, Emerson J, McNamara S, Joubran K, Retsch-Bogart G, Graff GR, et al. Baseline characteristics and factors associated with nutritional and pulmonary status at enrollment in the Cystic Fibrosis EPIC Observational Cohort. Pediatr Pulmonol. 2010;45:934-44.

25. Wagener JS, Zemanick ET, Sontag MK. Newborn screening for cystic fibrosis. Curr Opin Pediatr. 2012;24:329-35.

26. Yen EH, Quinton $H$, Borowitz D. Better nutritional status in early childhood is associated with improved clinical outcomes and survival in patients with cystic fibrosis. J Pediatr. 2013;162:530-5.

27. Scaparrotta A, Di Pillo S, Attanasi M, Consilvio NP, Cingolani A, Rapino D, et al. Growth failure in children with cystic fibrosis. J Pediatr Endocrinol Metab. 2012;25:393-405.

28. Blackman SM, Hsu S, Vanscoy LL, Collaco JM, Ritter SE, Naughton K, et al Genetic modifiers play a substantial role in diabetes complicating cystic fibrosis. J Clin Endocrinol Metab. 2009;94:1302-9.

29. Moran A, Dunitz J, Nathan B, Saeed A, Holme B, Thomas W. Cystic fibrosisrelated diabetes: current trends in prevalence, incidence, and mortality. Diabetes Care. 2009;32:1626-31.

30. Chamnan P, Shine BS, Haworth CS, Bilton D, Adler Al. Diabetes as a determinant of mortality in cystic fibrosis. Diabetes Care. 2010;33:311-6.

31. Laguna TA, Nathan BM, Moran A. Managing diabetes in cystic fibrosis. Diabetes Obes Metab. 2010;12:858-64.

32. Australia CF. Cystic Fibrosis in Australia 2009: 12th Annual Report from the Australian Cystic Fibrosis Data Registry. Sydney: Cystic Fibrosis Australia; 2011.

33. Gorter RR, Karimi A, Sleeboom C, Kneepkens CMF, Heij HA. Clinical and genetic characteristics of meconium ileus in newborns with and without cystic fibrosis. J Pediatr Gastroenterol Nutr. 2010;50:569-72.

34. Paraskeva MA, Borg BM, Naughton MT. Spirometry. Aust Fam Physician. 2011:40:216-9.

35. Gibson LE, Cooke RE. A test for concentration of electrolytes in sweat in cystic fibrosis of the pancreas utilizing pilocarpine by iontophoresis. Pediatrics. 1959;23:545-9

36. Zhao J, Schloss PD, Kalikin LM, Carmody LA, Foster BK, Petrosino JF, et al. Decade-long bacterial community dynamics in cystic fibrosis airways. Proc Natl Acad Sci. 2012;109:5809-14.

37. Quinton P, Molyneux L, Ip W, Dupuis A, Avolio J, Tullis E, et al. $\beta$-adrenergic sweat secretion as a diagnostic test for cystic fibrosis. Am J Respir Crit Care Med. 2012;186:732-9.

38. Sousa M, Servidoni MF, Vinagre AM, Ramalho AS, Bonadia LC, Felício V, et al. Measurements of CFTR-mediated $\mathrm{Cl}$ - secretion in human rectal biopsies constitute a robust biomarker for cystic fibrosis diagnostic and prognosis. PLoS One. 2012;7:e47708.

39. Guss AM, Roeselers G, Newton IL, Young CR, Klepac-Ceraj V, Lory S, et al. Phylogenetic and metabolic diversity of bacteria associated with cystic fibrosis. ISME J. 2011:5:20-9.

40. Park JE, Yung R, Stefanowicz D, Shumansky K, Akhabir L, Durie PR, et al. Cystic fibrosis modifier genes related to Pseudomonas aeruginosa infection. Genes Immun. 2011;12:370-7.

41. Marson FA, Bertuzzo CS, Ribeiro AF, Ribeiro JD. Polymorphisms in ADRB2 gene can modulate the response to bronchodilators and the severity of cystic fibrosis. BMC Pulm Med. 2012;12:50.

42. Marson FAL, Bertuzzo CS, Ribeiro MÂ, Ribeiro AF, Ribeiro JD. Screening for F508del as a first step in the molecular diagnosis of cystic fibrosis. J Bras Pneumol. 2013;39:306-16.

43. Bonadia LC, Marson FAL, Ribeiro JD, Paschoal IA, Pereira MC, Ribeiro AF, et al. CFTR genotype and clinical outcomes of adult patients carried as cystic fibrosis disease. Gene. 2014;540:183-90.
44. Bieger AM, Marson FA, Bertuzzo CS. Prevalence of $\Delta$ F508 mutation in the cystic fibrosis transmembrane conductance regulator gene among cystic fibrosis patients from a Brazilian referral center. J Pediatr. 2012:88:531-4

45. Tuchman LK, Schwartz LA, Sawicki GS, Britto MT. Cystic fibrosis and transition to adult medical care. Pediatrics. 2010;25:566-73.

doi:10.1186/1471-2466-15-3

Cite this article as: Marson et al:: Demographic, clinical, and laboratory parameters of cystic fibrosis during the last two decades: a comparative analysis. BMC Pulmonary Medicine 2015 15:3.

\section{Submit your next manuscript to BioMed Central and take full advantage of:}

- Convenient online submission

- Thorough peer review

- No space constraints or color figure charges

- Immediate publication on acceptance

- Inclusion in PubMed, CAS, Scopus and Google Scholar

- Research which is freely available for redistribution 